\title{
Protection between strains of Passion fruit woodiness virus in sunnhemp ${ }^{1}$
}

\author{
Quelmo S. Novaes ${ }^{1} \&$ Jorge A. M. Rezende ${ }^{2 * *}$ \\ ${ }^{1}$ Departamento de Fitotecnia e Zootecnia, Universidade Estadual do Sudoeste da Bahia, CEP 45083-900, Vitória da \\ Conquista, BA; ${ }^{2}$ Departamento de Entomologia, Fitopatologia e Zoologia Agrícola, Escola Superior de Agricultura \\ "Luiz de Queiroz", Universidade de São Paulo, CEP 13418-900, Piracicaba, SP, e-mail: jamrezen@esalq.usp.br
}

(Accepted for publication on 11/11/2004)

Corresponding author: Jorge Alberto Marques Rezende

NOVAES, Q.S. \& REZENDE, J.A.M. Protection between strains of Passion fruit woodiness virus in sunnhemp. Fitopatologia Brasileira 30:307-311. 2005.

\begin{abstract}
The main objective of the present study was to evaluate the effect of the sunhemp (Crotalaria juncea) host species on the protective ability of two mild strains of Passion fruit woodiness virus (PWV), named F-101 and F-144, which had failed to protect passion flowers (Passiflora edulis f. flavicarpa) in previous experiments. The nucleotide sequences of the capsid protein $(C P)$ gene and the 3'-non-translated region (3'-NTR) of these mild strains and the severe strain of PWV-SP were compared to confirm their relationship. The results of two protective tests with sunhemp plants in the greenhouse and one test under field conditions showed that all plants infected with either mild strain were protected against infection and/or symptom expression of the severe strain of PWV-SP. Evaluation of the relative concentration of the mild strains in sun hemp leaves showed an apparent uniformity in virus distribution in the leaf tissues, different than that which was previously reported for these mild strains in passion flower leaves. These results agree with previous studies that showed the effect of the concentration of the protective strains and the host species in the protection process.
\end{abstract}

Additional keywords: Crotalaria juncea, cross protection, potyvirus.

\section{RESUMO}

Proteção entre estirpes do Passion fruit woodiness virus em crotalária

Este trabalho teve por objetivo estudar o efeito em crotalária (Crotalaria juncea) em testes de proteção utilizando duas estirpes fracas do Passion fruit woodiness virus (PWV), denominadas F-101 e F-144, as quais falharam na proteção, de maracujazeiros (Passiflora edulis f. flavicarpa) contra a estirpe severa PWV-SP em experimentos anteriores. Para a confirmação da relação entre as estirpes fracas e a estirpe severa PWV-SP foram obtidas as seqüências de nucleotídeos do gene da capa protéica e da região 3' não traduzida. Os resultados de dois testes de proteção em plantas de crotalária em casa de vegetação e um em campo mostraram que todas as plantas infectadas com as estirpes fracas ficaram protegidas contra a infecção e/ou expressão dos sintomas da estirpe severa (PWV-SP). Avaliações da concentração relativa das estirpes fracas nas folhas da crotalária mostraram uma aparente uniformidade na distribuição do vírus nos tecidos foliares, diferente do que foi relatado sobre a distribuição destas mesmas estirpes em folhas de maracujazeiro. Estes resultados estão de acordo com outros relatos na literatura que mostraram o efeito da concentração das estirpes fracas e da espécie hospedeira no processo de proteção.

Palavras-chave adicionais: Crotalaria juncea, premunização, potyvirus.

Passion fruit woodiness disease was first reported in Brazil in the 70's affecting yellow passion fruit (Passiflora edulis Sims f. flavicarpa Degener) and sweet passion fruit plants ( $P$. alata Dryand.). Based on morphological studies of virus particles, host range and serology, the causal agent of this disease was identified as a strain of Passion fruit woodiness virus (PWV), family Potyviridade, genus Potyvirus, (Yamashiro \& Chagas, 1979; Chagas et al., 1981). Using the same criteria, the identification of PWV was constant in subsequent studies in passion fruit orchards in other regions of the country. More recently, however, molecular studies based on the amino acid sequences of the

\footnotetext{
${ }^{1}$ Parte da Tese de Doutorado do primeiro autor. ESALQ, Universidade de São Paulo, 2002.

***Bolsista do CNPq.
}

capsid protein $(\mathrm{CP})$ of several Brazilian isolates of this potyvirus showed they shared more than $85 \%$ identity with strains of Cowpea aphid borne mosaic virus (CABMV) and $76 \%-68 \%$ identity with strains of PWV (Santana et al., 1999; Nascimento et al., 2004). The CABMV and the South African passiflora virus (SAPV), recognized as a strain of CABMV, have also been described as causing passion fruit woodiness in Africa (Brand et al., 1993; McKern et al., 1994). Since there has not been any official change in the nomenclature for the causal agent of the passion fruit woodiness disease in Brazil, it will be treated as PWV in this study.

Like all the species of the genus Potyvirus, the PWV is transmitted in a non-persistent way by different species of aphids (Taylor \& Greber, 1973). The PWV is disseminated throughout Brazil and causes the most important viral disease 
of passio nflower because it is frequently associated with significant quantitative and qualitative yield loss. Besides yellow and sweet passion fruit, PWV also infects other species of Passifloraceae family that are of little economic value (Costa, 1994). The virus can also be transmitted experimentally to several species of the Fabaceae family, including sunhemp (Crotalaria juncea L.).

The control of passion fruit woodiness disease has been very difficult for several reasons. The planting of new passion fruit vines almost always takes place near old abandoned infected orchards, which serve as the source of inoculum. Dissemination of the virus is quickly carried out by several species of aphids that do not colonize passion flower, thus making it difficult to control the vectors by insecticide spraying. The genetic material available does not have resistance to infection or tolerance to the disease. Recently, Novaes \& Rezende (2003) studied the possible use of mild strain protection for the control of the disease, but found out that the selected mild strains did not offer protection against infection by severe PWV strains. The experimental results indicated that the lack of protection was apparently associated with low concentrations and/or irregular distribution of the mild strains in leaf tissues of passion fruit plants, creating available sites for super infection with severe strains of the virus. Apparently more competitive, the severe strains invade the plant systemically causing disease.

The main objective of the present study was to evaluate the effect of sunnhemp host species on the protective ability of mild strains of PWV, under greenhouse and field conditions. The relative concentration of the mild strains of PWV in sunhemp plants was also evaluated.

Two mild strains of PWV, F-101 and F-144, obtained by Novaes \& Rezende (2003), were used for cross protection tests. The protected plants were challenged with a severe strain of PWV, obtained from passion fruit vines in Vera Cruz County, State of São Paulo (PWV-SP) and maintained in passion fruit plants in a greenhouse. The mechanical inoculation of the mild strains and the subsequent challenge inoculation with the severe strain of PWV were accomplished by a conventional procedure, using inoculum dilution of 1:20 in $0.02 \mathrm{M}$ phosphate buffer, $\mathrm{pH}$ 7.0. The inoculum was rubbed on leaves previously dusted with carborundum. All the inoculated plants were periodically evaluated for symptoms, using a scale ranging from 0 to 3 , where $0=$ no symptoms, 1 = mild mosaic, $2=$ severe yellow mosaic, and $3=$ severe yellow mosaic and necrotic lesions in the leaves and the stem. Confirmation of infection with PWV strains were done by indirect DAS-ELISA, according to the procedures described by Novaes \& Rezende (1999), using polyclonal anti-serum raised in rabbits and hens, available at the Virology Laboratory of the Departamento de Entomologia, Fitopatologia e Zoologia Agrícola, ESALQ/USP.

Two cross protection tests were performed in sunhemp plants in the greenhouse. In the first test, the mild strain F-101 was mechanically inoculated into ten plants at the cotyledonal stage. Fifteen days after the protective inoculation, the infection in these plants was confirmed by indirect DASELISA and eight plants were challenged with the severe strain PWV-SP. In four of these plants, the severe strain was mechanically inoculated into two expanded leaves at the apex. In the other four plants, the inoculation was done into two leaves in the middle part of the stem. Two healthy plants of the same age were also inoculated with PWV-SP at the same time. Two plants inoculated with mild strains were not challenged, and two others were kept healthy.

Mild strains F-101 and F-144 were used to inoculate each of the ten sunnhemp plants at the cotyledonal stage in the second experiment. Confirmation of virus infection was done as previously described. After ten days, five plants inoculated with each of the mild strains were challenged with PWV-SP on two expanded leaves of the plant apex. Five healthy plants of the same age were also inoculated with PWVSP at the same time. Five plants inoculated with the mild strains were not challenged and five plants were kept healthy. The plants were maintained in the greenhouse for symptoms evaluation.

Before challenging the protected plants in the second experiment, leaf samples from eight plants inoculated with each of the mild strains were collected for evaluation of the relative concentration of the virus. This evaluation was based on the absorbance values of the indirect DAS-ELISA test, since these values, in a specific extract dilution, are directly proportional to the decimal logarithm of the virus concentration in the sample (Novaes \& Rezende, 1999). Five expanded leaves near the apex of these plants were selected and a $1 \mathrm{~cm}$ in diameter disc was extracted from the center of each leaf. Leaf discs were ground separately in PBS-Tween buffer $\left(0,0015 \mathrm{M} \mathrm{KH}_{2} \mathrm{PO}_{4}, 0,14 \mathrm{M} \mathrm{NaCl}, 0,004 \mathrm{M} \mathrm{Na}_{2} \mathrm{HPO}_{4}\right.$, $0,003 \mathrm{M} \mathrm{KCl}, \mathrm{pH} 7,4+0,5 \mathrm{ml}$ Tween $20 \mathrm{l}^{-1}$ ), diluted 1:50 (w/ v). All samples were evaluated by indirect DAS-ELISA using appropriate negative (extract of healthy sunhemp) and positive (PWV-SP) controls. All samples were tested in duplicated wells and the absorbance values at $405 \mathrm{~nm}$ were obtained in a Metertech $\Sigma 960$ ELISA reader. Average absorbance values equal to or above 3 times the absorbance of healthy samples were considered positive and used to compare the relative concentration of the mild strains in the leaf tissues.

For the protection test in the field, sunhemp plants were grown in pots under greenhouse conditions. Protective inoculation with mild strains F-101 and F-144 was carried out at the cotyledonal stage. Ten plants were inoculated with each mild strain and the infection was confirmed 20 days later by indirect DAS-ELISA. These plants, together with ten healthy plants of the same age, were transplanted to the field, spaced $0.5 \mathrm{~m}$ apart, in rows $1.0 \mathrm{~m}$ distant from each other. Half of the plants inoculated with each mild strain were mechanically challenged with PWV-SP on two expanded leaves of the plant apex. Five healthy plants were also inoculated with the severe strain, while the other five were mock-inoculated. The plants were evaluated for up to 60 days after the challenge inoculation based on symptom expression and development. 
In order to confirm the relationship between the mild and severe strains of PWV, the nucleotide sequences of the $C P$ gene and the 3'-NTR were obtained for comparison. Total RNA was extracted from plants separately infected with mild strains F-101 and F-144 and with the severe strain PWV-SP, according to the methodology described by Gibbs \& Mackenzie (1997). The RNA was used as a template to amplify the 3'- terminal by reverse transcription and polymerase chain reaction (RT-PCR). First strand cDNA synthesis was primed on viral RNA using the PV1 primer (5'-(T) ${ }_{17}$ AGC-3 $\left.{ }^{\circ}\right)$. Complementary DNA was subsequently used for PCR reaction using primers $\mathrm{PV} 1$ and $\mathrm{PV} 2\left(5^{\prime}-\mathrm{GG}(\mathrm{T} / \mathrm{C} / \mathrm{G}) \mathrm{AA}(\mathrm{C} / \mathrm{T}) \mathrm{AG}(\mathrm{C} /\right.$ T)GG(G/T/A)CA(A/G)CC-3'). Primers were designed according to Gibbs \& Mackenzie (1997) with modifications. The PCR was performed using Taq DNA polymerase (Promega Corporation) and the thermocycler (MJ Research PTC 200) regime was as follows: $2 \mathrm{~min}$ at $94^{\circ} \mathrm{C}$, followed by 35 additional cycles of $1 \mathrm{~min}$ at $94{ }^{\circ} \mathrm{C}, 2 \mathrm{~min}$ at $52^{\circ} \mathrm{C}$ and 3 min at $72{ }^{\circ} \mathrm{C}$, and finalizing at $72{ }^{\circ} \mathrm{C}$ for $10 \mathrm{~min}$. Amplified products were ligated into the pGem-T Vector (Promega) and cloned as described by Sambrook et al. (1989). The sequence of each cDNA clone was determined using the Dyenamic ${ }^{\mathrm{TM}}$ ET Terminator Cycle Sequencing Kit (Amersham Pharmacia Biotech) in an ABI Prism 377 automatic sequencer. The consensus nucleotide sequences of the mild and severe strains were obtained by the DNATools program (http://www.crc.dk/ dnatools) and the deduced amino acid sequences of the CP was obtained by the Translate program (http://ca.expasy.org/ tools/dna.html). The identity between the strains was calculated with the CLUSTAL W program.

The results of the two protective tests in sun hemp plants under greenhouse conditions are shown in Table 1 . During the two-month evaluation period, all the plants inoculated with mild strains F-101 and F-144 were protected against the severe strain PWV-SP, since they displayed only the mild symptoms characteristic of infection by these strains, without developing the severe disease symptoms caused by PWV-SP. Likewise, plants only inoculated with the mild strains and not challenged with PWV-SP displayed only mild disease symptoms. Healthy plants inoculated with PWV-SP showed severe symptoms of yellow mosaic and necrotic lesions in the leaves and in the stem, 20 days after the inoculation.

The results of the protective effect of the mild strains F-101 and F-144 in sunhemp plants in the field were parallel to that carried out in the greenhouse. Three out of five unprotected plants inoculated with PWV-SP showed severe yellow mosaic symptoms, necrotic lesions in the leaves and in the stem, thirty days after the inoculation. All plants protected separately with mild strains F-101 and F-144 and challenged with PWV-SP showed only mild mosaic symptoms and absence of necrotic lesions in the stem during the twomonth evaluation period. Protected plants not challenged by PWV-SP showed similar symptoms. The healthy control plants exposed to natural infection were symptomless during the evaluation period of this study.

The relative concentration of mild strains F-101 and F-144 in sunhemp leaves, based on ELISA readings, is shown in Figures 1 and 2, respectively. Each graphic represents the average absorbance values of disc extracts from five leaves of eight plants. Leaves were numbered 1 - 5 from the middle part of the plant to the apex. The mild strains in the leaves of all tested plants were detected by indirect DAS-ELISA, following the criteria used in this study. The highest absorbance values indicate a higher viral concentration in the tissues. Whatever the virus strain inoculated, the concentration in the leaf tissues was apparently uniform in most of the plants tested, independent of the position of the leaf in the stem.

Molecular analysis of the $C P$ gene of the mild strains F-101 (AY433951) and F-144 (AY505342) showed that they share $99.7 \%$ identity at the nucleotide level. When these strains

TABLE 1 - Number of sunnhemp (Crotalaria juncea) plants, in two independent experiments in a greenhouse, taking into account the severity of symptoms in two phases of protection evaluation with mild strains of Passion fruit woodiness virus (PWV)

\begin{tabular}{lccc}
\hline \hline \multirow{2}{*}{ Treatment } & $\begin{array}{c}\text { No. of tested } \\
\text { plants }\end{array}$ & \multicolumn{2}{c}{ No. of plants with highest symptom grade * } \\
\cline { 3 - 4 } & & 20 days after challenge & 60 days after challenge \\
\hline Experiment 1 & 8 & 0 & 0 \\
Mild F-101 + PWV-SP** & 2 & $\mathbf{0}$ & $\mathbf{0}$ \\
Mild F-101 & 2 & $\mathbf{0}$ & $\mathbf{0}$ \\
Healthy & 2 & 2 & 2 \\
Unprotected, inoculated with/ PWV-SP & & & $\mathbf{0}$ \\
Experiment 2 & 5 & $\mathbf{0}$ & $\mathbf{0}$ \\
Mild F-101 + PWV-SP & 5 & $\mathbf{0}$ & 0 \\
Mild F-144 + PWV-SP & 5 & $\mathbf{0}$ & $\mathbf{0}$ \\
Mild F-101 & 5 & $\mathbf{0}$ & $\mathbf{0}$ \\
Mild F-144 & 5 & $\mathbf{0}$ & 5 \\
Healthy & 5 & & \\
Unprotected, inoculated with/ PWV-SP & &
\end{tabular}




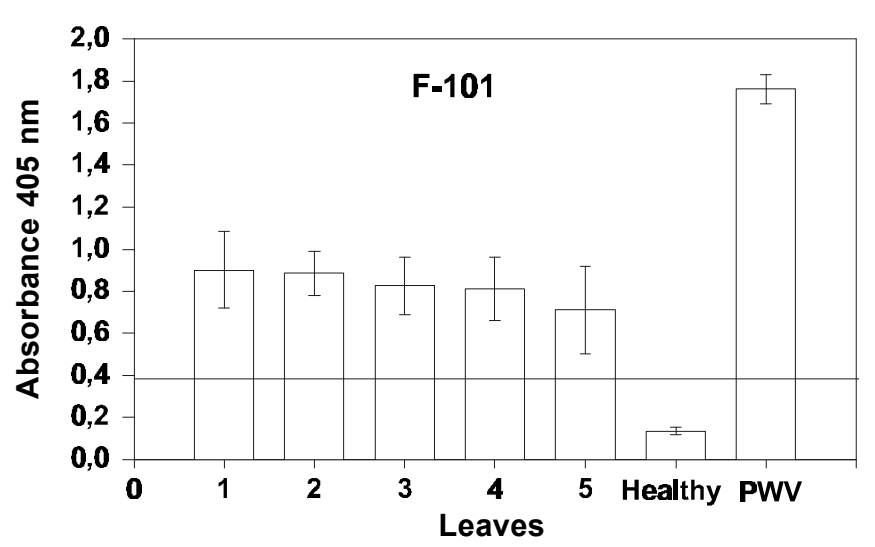

FIG. 1 - Average absorbance values of extracts of five different leaves, collected from eight sunnhemp (Crotalaria juncea) plants, protected with mild strain F-101 of Passion fruit woodiness virus, in DASELISA indirect test. (Horizontal continuous line indicates a value equal to three times the average absorbance of a healthy plant extract $=0,38)$. PWV $=$ positive control.

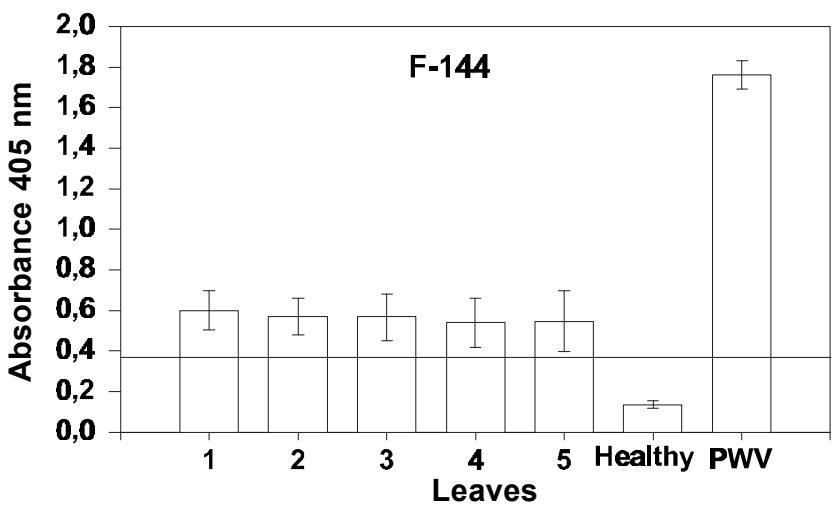

FIG. 2 - Average absorbance values of extracts of five different leaves, collected from eight sunnhemp (Crotalaria juncea) plants, protected with mild strain F-144 of Passion fruit woodiness virus, in DASELISA indirect test. (Horizontal continuous line indicates a value equal to three times the average absorbance of a healthy plant extract $=0,38)$. PWV $=$ positive control.

were compared with the severe strain PWV-SP (AY433950), the identities were $97.2 \%$ and $97.0 \%$, respectively. The nucleotide sequences of the 3'-NTR showed an identity of $99.6 \%$ between the mild strains. When both mild strains were compared with PWV-SP, the nucleotide sequence of the 3'NTR shared $95.2 \%$ and $94.8 \%$ identity, respectively. The deduced amino acid sequences of the coat protein showed an identity of $100 \%$ between the mild strains. When these sequences were compared with PWV-SP strain, the identity was $98.5 \%$.

Novaes \& Rezende (2003), carrying out studies on mild strain protection in passion fruit plants (including F-101 and F-144, among others), reported that they did not offer protection against superinfection with severe strains of the virus. The results of the present study, to the contrary, showed that the mild strains F-101 and F-144 protected sunhemp plants against superinfection with the severe strain. The failure of the mild strains in protecting passion fruit plants was attributed to an apparently uneven distribution and concentration of the mild strains in the infected leaf tissues, thus allowing for the existence of available infection sites for the establishment of the challenging severe strain later inoculated (Novaes \& Rezende, 2003). The evaluation of the distribution of the mild strain in passion fruit plants was based on the relative concentration of the virus in extracts of leaf discs from different plants by indirect DAS-ELISA. From ten passion flower infected with mild strain F-101, 150 leaf discs were collected, but the virus was only detected by ELISA in 42 disc extracts. For plants infected with mild strain F-144, the serological assay was able to detect the virus in 53 out of 150 leaf disc extracts. In sunhemp, however, both mild strains were detected by indirect DAS-ELISA in all 80 leaf disc extracts, suggesting that in this host the mild strains are apparently more evenly distributed and also probably reach higher concentrations than in passion fruit plants, which allowed for full protection in all tested plants.

These results are in accordance with previous studies that showed the effect of the concentration of the protective strains and the host species in the protection process. Fulton (1951) and Sherwood \& Fulton (1982) showed that plants of Nicotiana sylvestris Spegaz \& Gomes infected with a Tobacco mosaic virus (TMV), genus Tobamovirus, strain that causes mosaic were superinfected when inoculated with another strain that induced local lesions. The superinfection, nevertheless, was restricted to dark green areas that had lower concentration of the first strain than neighboring light green areas. The effect of the concentration of the protective strain was also reported by Rezende \& Sherwood (1991) in tests with the same strains of TMV in plants of $N$. tabacum L. cvs. Samsun and Xanthi. As for the role of the host species in protection between strains of viruses, Rezende et al. (1992) showed that plants of Arabidopsis thaliana (L.) Heynh. infected with TMV-P strain and challenged with TMV-C strain allowed for the multiplication of the latter in the challenge inoculated leaves, in levels detected by the ELISA test. On the other hand, the challenge strain did not invade the plants systemically. The same strains were used in reciprocating protection tests in $N$. tabacum cvs. Samsun and Xanthi. In all the plants where the multiplication of the challenging strain in the inoculated leaves occurred, it was detected some days later in the leaves of the apex. The interference of the host species in the protection success between strains of the same virus was also demonstrated by Singh \& Singh (1995). These authors verified that some potato (Solanum tuberosum L.) cultivars that had been inoculated with the common strain of Potato virus $Y\left(\mathrm{PVY}^{0}\right)$, family Potyviridae, genus Potyvirus, were not protected against a strain that causes necrosis $\left(\mathrm{PVY}^{\mathrm{N}}\right)$. However, plants of Solanum brachycarpum Correll inoculated with $\mathrm{PVY}^{0}$ and challenged with $\mathrm{PVY}^{\mathrm{N}}$, did not show the characteristic symptoms of the challenging strain. 
The protection of sunhemp with mild strains of PWV might not have any practical value. However, it reinforces the hypothesis that the selection of passion flower clones that allow for a higher multiplication of mild strains or that the selection of other mild strains with higher invasive power, could make pre-immunization viable for controlling woodiness disease in passion fruits in fields (Novaes \& Rezende, 2003).

\section{LITERATURE CITED}

BRAND, R.J., BURGER, J.T. \& RYBICKI, E.P. Cloning, sequencing, and expression in Escherichia coli of the coat protein gene of a new potyvirus infection South African Passiflora. Archives of Virology 128:29-41. 1993

CHAGAS, C.M., KITAJIMA, E.W., LIN, M.T., GAMA, M.I.C.S. \& YAMASHIRO T. Grave moléstia em maracujá amarelo (Passiflora edulis $\mathrm{f}$. flavicarpa) no Estado da Bahia, causado por um isolado do vírus do "woodiness" do maracujá. Fitopatologia Brasileira 6:259268. 1981.

COSTA, A.F. Pesquisa e extensão com maracujá em Pernambuco. In: São José, A.R. (Ed) Maracujá: produção e mercado. Vitória da Conquista. Universidade Estadual do Sudoeste da Bahia. 1994. pp.138-143.

FULTON, R.W. Superinfection by strains of tobacco mosaic virus. Phytopathology 7:579-592. 1951.

GIBBS, A. \& MACKENZIE, A. A primer pair for amplifying part of the genome of all potyvirids by RT-PCR. Journal of Virological Methods 63:9-16. 1997.

NASCIMENTO, A.V.S., SOUZA, A.R.R., ALFENAS, P.F., ANDRADE, G.P., CARVALHO, M.G., PIO-RIBEIRO, G. \& ZERBINI, F.M. Análise filogenética de potyvirus causando endurecimento dos frutos do maracujazeiro no Nordeste do Brasil. Fitopatologia Brasileira 29:378-383. 2004.

NOVAES, Q.S. \& REZENDE, J.A.M. Possível aplicação do DASELISA indireto na seleção de maracujazeiro tolerante ao "Passion fruit woodiness virus”. Fitopatologia Brasileira 24:76-79. 1999.

NOVAES, Q.S. \& REZENDE, J.A.M. Selected mild strains of Passion fruit woodiness virus (PWV) fail to protect pre-immunized vines in Brazil. Scientia Agricola 60:699-708. 2003

McKERN, N.M., STRIKE, P.M., BARNETT, O.W., DIJKSTRA, J., SHUKLA, D.D. \& WARD, C.W. Cowpea aphid borne mosaic virus-Morocco and South African Passiflora virus are strains of the same potyvirus. Archives of Virology 136:207-217. 1994

REZENDE, J.A.M. \& SHERWOOD, J.L. Breakdown of cross protection between strains of tobacco mosaic virus due to susceptibility of dark green areas to superinfection. Phytopathology 81:1490-1496. 1991

REZENDE, J.A.M., URBAN, L., SHERWOOD, J.L. \& MELCHER, U. Host effect on cross protection between two strains of tobacco mosaic virus. Journal of Phytopathology 136:147-153. 1992

SAMBROOK, J., FRITSCH, E.F. \& MANIATIS, T. Molecular Cloning: A laboratory manual. $2^{\text {nd }}$ ed. New York. Cold Spring Harbor Laboratory Press. 1989

SANTANA, E.N., BRAZ, A.S.K., TORRES, L.B., ZAMBOLIM, E.M. \& ZERBINI, F.M. Molecular characterization of Potyvirus isolates causing passionfruit woodiness in Brazil. Virus Reviews and Research 47:153. 1999

SHERWOOD, J.L. \& FULTON, R.W. The specific involvement of coat protein in tobacco mosaic virus cross protection. Virology 119:150-158. 1982

SINGH, M. \& SINGH, R.P. Host dependent cross-protection between $\mathrm{PVY}^{\mathrm{N}}, \mathrm{PVY}^{0}$, and PVA in potato cultivars and Solanum brachycarpum. Canadian Journal of Plant Pathology 17:82-86. 1995

TAYLOR, R.H. \& GREBER, R.S. Passion fruit woodiness virus. CMI/AAB, (Description of Plant Viruses, 122). 1973

YAMASHIRO, T. \& CHAGAS, C.M. Ocorrência de grave virose em maracujá amarelo (Passiflora edulis f. flavicarpa Deg.) no Estado da Bahia. Anais, $5^{\circ}$ Congresso Brasileiro de Fruticultura, Pelotas, RS. 1979. pp.915-917. 